\title{
Assessment of the susceptibility status of Aedes aegypti (Diptera: Culicidae) populations to pyriproxyfen and malathion in a nation-wide monitoring of insecticide resistance performed in Brazil from 2017 to 2018
}

Kauara Brito Campos ${ }^{1,2}$, Ademir Jesus Martins ${ }^{3}$, Cynara de Melo Rodovalho 3 , Diogo Fernandes Bellinato ${ }^{3}$, Luciana dos Santos Dias ${ }^{3}$, Maria de Lourdes da Graça Macoris ${ }^{4}$, Maria Teresa Macoris Andrighetti ${ }^{4}$, José Bento Pereira Lima ${ }^{3^{*}}$ (1) and Marcos Takashi Obara ${ }^{2}$

\begin{abstract}
Background: Chemical mosquito control using malathion has been applied in Brazil since 1985. To obtain chemical control effectiveness, vector susceptibility insecticide monitoring is required. This study aimed to describe bioassay standardizations and determine the susceptibility profile of Ae. aegypti populations to malathion and pyriproxyfen, used on a national scale in Brazil between 2017 and 2018, and discuss the observed impacts in arbovirus control.

Methods: The diagnostic-doses (DD) of pyriproxyfen and malathion were determined as the double of adult emergence inhibition (EI) and lethal doses for $99 \%$ of the Rockefeller reference strain, respectively. To monitor natural populations, sampling was performed in 132 Brazilian cities, using egg traps. Colonies were raised in the laboratory for one or two generations (F1 or F2) and submitted to susceptibility tests, where larvae were exposed to the pyriproxyfen DD $(0.03 \mu \mathrm{g} / \mathrm{l})$ and adults, to the malathion DD determined in the present study $(20 \mu \mathrm{g})$, in addition to the one established by the World Health Organization (WHO) DD (50 $\mu \mathrm{g})$ in a bottle assay. Dose-response (DR) bioassays with pyriproxyfen were performed on populations that did not achieve 98\% El in the DD assays.
\end{abstract}

Results: Susceptibility alterations to pyriproxyfen were recorded in six (4.5\%) Ae. aegypti populations from the states of Bahia and Ceará, with Resistance Ratios (RR $\left.\mathrm{R}_{95}\right)$ ranging from 1.51 to 3.58. Concerning malathion, 73 (55.3\%) populations distributed throughout the country were resistant when exposed to the local DD $20 \mathrm{\mu g} / \mathrm{bottle}$. On the other hand, no population was resistant, and only 10 (7.6\%) populations in eight states were considered as exhibiting decreased susceptibility (mortality ratios between 90 and 98\%) when exposed to the WHO DD (50 $\mathrm{\mu g} / \mathrm{bottle}$ ).

Conclusions: The feasibility of conducting an insecticide resistance monitoring action on a nation-wide scale was confirmed herein, employing standardized and strongly coordinated sampling methods and laboratory bioassays. Brazilian Ae. aegypti populations exhibiting decreased susceptibility to pyriproxyfen were identified. The local DD for malathion was more sensitive than the WHO DD for early decreased susceptibility detection.

\footnotetext{
${ }^{*}$ Correspondence: jbento@ioc.fiocruz.br

${ }^{3}$ Laboratório de Fisiologia e Controle de Artrópodes Vetores, Instituto

Oswaldo Cruz, Rua Francisco Manuel no 102, Bairro Benfica, Rio de

Janeiro/Rio de Janeiro State CEP 20911-270, Brasil

Full list of author information is available at the end of the article
}

c) The Author(s) 2020. This article is licensed under a Creative Commons Attribution 4.0 International License, which permits use, sharing, adaptation, distribution and reproduction in any medium or format, as long as you give appropriate credit to the original author(s) and the source, provide a link to the Creative Commons licence, and indicate if changes were made. The images or other third party material in this article are included in the article's Creative Commons licence, unless indicated otherwise in a credit line to the material. If material is not included in the article's Creative Commons licence and your intended use is not permitted by statutory regulation or exceeds the permitted use, you will need to obtain permission directly from the copyright holder. To view a copy of this licence, visit http://creativeco mmons.org/licenses/by/4.0/. The Creative Commons Public Domain Dedication waiver (http://creativecommons.org/publicdomain/ zero/1.0/) applies to the data made available in this article, unless otherwise stated in a credit line to the data. 
Keywords: Arboviruses, Aedes aegypti, Insecticide resistance, Juvenile hormones, Organophosphate insecticides

\section{Background}

In recent decades, the incidence of Aedes-borne diseases, such as dengue, Zika, chikungunya and yellow fever, has increased significantly worldwide [1]. Actions against the Aedes (Stegomyia) aegypti (Linnaeus, 1762) are mainly based on chemical and mechanical controls aiming to reduce infestation, while social mobilization, environmental management and legislation protections seeking to maintain environments free of larval breeding sites are also applied. Controlling the insect in its immature phases (egg, larva and pupa) is more feasible, since development occurs in specific and restricted locations, unlike the adult phase, which may be dispersed throughout various environments. The most effective form of vector control is environmental management involving mechanical reservoir removal, although arbovirus transmission blocking usually comprises chemical insecticide applications, aiming at rapidly reducing mosquito populations [2].

The Brazilian Ministry of Health $(\mathrm{MoH})$ provides insecticides pre-qualified by the World Health Organization (WHO) to all Brazilian states for the chemical control of Ae. aegypti. This process ensures that the entire country employs trusted products concerning environmental safety, toxicity and effectiveness [3]. In addition, the Brazilian $\mathrm{MoH}$ evaluates all compounds under local conditions prior to purchases. The application of larvicides by public agents is recommended in domestic reservoirs that cannot be covered or eliminated, every two months. In addition, spatial insecticide application cycles are recommended whenever arbovirus transmission occurs in a given area [4]. Thus, public health actions used to control Ae. aegypti in Brazil consume an expressive amount of insecticides each year, considering, for example, that about 4136 Brazilian municipalities registered dengue cases from 2014 to 2017 [5].

With the intensive and continuous deployment of the same active ingredients, resistant individuals in a given population are favorably selected, potentially compromising insecticide efficacy. A rational chemical control strategy should be based on detailed knowledge concerning territorial vector distribution, susceptibility to compounds belonging to different classes and the mechanisms involved in resistance selection, in order to reduce vector infestation levels and consequent arbovirus transmission [6]. Most Ae. aegypti populations in America tested for DDT exhibited resistance to this compound $(86.7 \pm 0.1 \%)$. High frequencies of resistant populations were also observed for temephos and deltamethrin (75.7 $\pm 0.1 \%$ and $33 \pm 0.1 \%$, respectively). These patterns can be explained by the chronic and frequent use of these insecticides in the continent [7].

In Brazil, insecticide resistance in Ae. aegypti was first recorded for the organophosphate (OP) larvicide temephos in populations from the states of Goiás and São Paulo, in 1995 [8]. A few years later, a reduction in temephos resistance was detected in field studies, as well as decreased susceptibility to the adulticide OP fenitrothion and malathion in several Ae. aegypti populations throughout the country [9]. In 2001, resistance to the adulticide pyrethroid (PY) cypermethrin was detected in populations from the state of Rio de Janeiro [10]. Within this scenario, the National Dengue Control Programme (PNCD, Portuguese acronym) implemented the National Network for Monitoring the Resistance of Ae aegypti to Insecticides (MoReNAa, Portuguese acronym) in 1999, with the purpose of providing technical support to decisions regarding the chemical control management of Ae. aegypti. The MoReNAa Network carried out a systematic insecticide resistance monitoring (IRM) of natural Ae. aegypti populations in Brazil to insecticides used in governmental campaigns, in areas considered as either priority or strategic for vector control interventions $[11,12]$.

Mosquito populations from about 80 cities, including those presenting the highest incidence of dengue cases, most populated, presenting high mosquito infestation indices and all state capitals, were evaluated every two years. Quantitative and qualitative bioassays for larvae and adult resistance detection were performed according to WHO and Centers for Disease Control and Prevention (CDC) methodologies. Biochemical assays for the quantification of enzymatic activity alterations and $k d r$ mutation genotyping were employed to investigate the molecular basis of insecticide resistance selection and identify resistance mechanisms. The Network aided in supporting the technical decision concerning insecticide replacement until 2012, when the last monitoring round was carried out $[11,12]$. Based on the increasing detection of Ae. aegypti populations resistant to temephos, this compound was gradually replaced by insect growth regulators (IGR) since 2009 throughout the entire country, adopting the chitin synthesis inhibitor diflubenzuron, followed by novaluron [9].

The adoption of the IGR pyriproxyfen began in 2014, based on the intention of rotating insecticides presenting distinct modes of action. As a juvenile hormone analogue, this product prolongs the immature stage of the 
mosquito for up to 20 days, inhibiting the development of imaginal characteristics. A complete metamorphosis is, therefore, compromised, with mortality occurring especially at the pupal stage or leading to the emergence of malformed adults [2]. Some reports indicating resistance to IGR are available, likely because of their recent employment for public health purposes. Some alterations in susceptibility to pyriproxyfen were observed in $A e$. aegypti populations from Martinique $\left(\mathrm{RR}_{50}\right.$ of $2.2, \mathrm{RR}_{95}$ of 1.9), in 2007 [13] and Ae. albopictus from the USA $\left(R_{50}\right.$ of 1.8-2.4) [14]. Higher resistance, however, was observed in Ae. aegypti from Malaysia $\left(\mathrm{RR}_{50}\right.$ of 6.1) [15] and from the USA ( $R_{50}$ of 38.7, $R_{90}$ of 81.5), in 2015 [16].

The OP malathion began being employed against adult mosquitoes through ultra-low-volume (ULV) and residual spraying applications in Brazil in 1985. In 1989, it was replaced by fenitrothion for residual spraying, which continued to be used in ULV treatment during the following ten years, when OPs were replaced by PYs for adult control. After years without being used to control Ae. aegypti adults, malathion was again adopted alongside the introduction of IGRs for larval control throughout the country since 2009 [9]. OPs are derived from phosphoric acid and its homologs, and their mechanism action acts on the inhibition of the cholinesterase enzyme [2]. Alterations in the susceptibility of Ae. aegypti to malathion have already been reported in countries in America, including Brazil [17, 18].

This study was developed with the aim of describing assay standardizations and resistance monitoring of Ae. aegypti populations to insecticides used in public health on a national scale in Brazil between 2017 and 2018, discussing the obtained findings. This monitoring was promoted by the Brazilian $\mathrm{MoH}$ and was the broadest evaluation ever carried out in a country of continental dimensions, resulting in the evaluation of mosquito populations from 132 cities during 17 months, in which over 137,000 larvae and 131,000 adults were tested. To the best of our knowledge, this is also the largest surveillance round concerning insecticide Ae. aegypti resistance monitoring on a global scale.

\section{Methods}

\section{Study populations}

The sampling points applied herein considered several areas throughout the Brazilian territory, covering a large number of close towns, in urban conglomerates with high population density, as suggested by Chediak et al. [19], preferentially in sites previously evaluated during the 12-year period MoReNAa Network effort, as described by Valle et al. [9]. This proposal was also adjusted considering the operational capacity of the municipal sampling teams, resulting in the selection of 146 cities for $A e$. aegypti samplings over the course of 17 months (Table 1, Fig. 1). Field Ae. aegypti populations were collected by the Endemic Control Agents of each city, using between 100 oviposition traps (ovitraps) in cities with up to 50,000 houses and 300 ovitraps in cities with over 500,000 houses, following the MoReNAa Network methodology [12].

To install the traps, houses evenly distributed in a grid pattern with full coverage of the urban territory were selected, in order to include regions presenting different infestation levels, and one trap was installed in a shaded area on the grounds of each selected house. A $0.04 \%$ yeast extract solution was used as an attractant for gravid females. In order to facilitate the preparation of this solution in the field, the agents were provided with a $50 \mathrm{ml}$ conical tube containing $6 \mathrm{~g}$ of a commercial yeast extract (Arma Zen ${ }^{\circledR}$; Tetra Gmbh, Melle, Germany). During the trap installation, the tubes were filled with tap water to the $50 \mathrm{ml}$ mark and homogenized. With the aid of plastic Pasteur pipettes, $1 \mathrm{ml}$ of this solution was added to the trap, which was then then filled with tap water to the $300 \mathrm{ml}$ mark. The traps were maintained in the households for 15 days, with one paddle and an attractive solution change at the end of the first week. The paddles containing the eggs were air-dried for 2-3 days prior to being sent to the laboratories.

The samplings were carried out between August 2017 and December 2018, following a staggered schedule so as not to overload the laboratories. Three preferred months were chosen for the samplings in each region of the country, observing the most adequate climatic conditions in order to obtain higher egg densities. The field-collected samples were initially sent to a central entomology laboratory in each respective state, which then confirmed the correct sampling registration at the origin sites and adequate paddle storage. The paddles were then shipped to the Physiology and Arthropod Vector Control Laboratory (Laboratório de Fisiologia e Controle de Artrópodes Vetores, LAFICAVE), at the Oswaldo Cruz Institute (IOC/Fiocruz), Rio de Janeiro/ $\mathrm{RJ}$, where the arrivals were recorded, forms were stored and populations labeled with a code known only by the study director, in order to maintain origin confidentiality. Half of the populations remained at the LAFICAVE, while the other half was sent to the Applied Entomology Laboratory (Laboratório de Entomologia Aplicada, LEnA), at the Endemic Control Superintendence (Superintendência de Controle de Endemias, SUCEN), Marília, SP. Aedes aegypti specimen sorting, colony maintenance and bioassays were performed by the LAFICAVE and LEnA laboratories. 


\section{Mosquito rearing}

Paddles containing eggs were submerged in dechlorinated water and hatched larvae were transferred to basins $(33 \times 24 \times 8 \mathrm{~cm})$ containing 11 of dechlorinated water and $100 \mathrm{mg}$ of fish food (TetraMin ${ }^{\circledR}$, Tetra Marine Granules; Tetra Gmbh, Melle, Germany) added every 3 days. The resulting adult Ae. aegypti mosquitoes were identified to the species level and sorted sex, with 500 females and 500 males maintained in cylindrical carton cages (16 $\mathrm{cm}$ in diameter $\times 18 \mathrm{~cm}$ high), where a $10 \%$ sucrose solution was offered ad libtum. When the number of females were insufficient for producing an F1 generation (less than 100 females), new field collections were requested.

In order to produce eggs for the next generation, females were additionally fed blood from guinea pigs (Cavia Porcellus - Linnaeus, 1758) 3 days post-emergence. Alternatively, females were offered to feed on citrated rabbit blood through a Hemotek reservoir membrane feeder (Discovery Workshops, Accrington, UK), containing $6 \mathrm{ml}$ of blood covered with a parafilm membrane, sealed with a rubber ring, at $37{ }^{\circ} \mathrm{C}$ for $1 \mathrm{~h}$. F1 generation mosquitoes were employed in the bioassays, although an F2 generation was required whenever the number of $\mathrm{F} 1$ generation individuals to perform all larvae and adult assays was insufficient.

Insectaries were maintained under controlled temperature $\left(26 \pm 2{ }^{\circ} \mathrm{C}\right)$ and humidity $(70 \pm 10 \%)$ following the Fiocruz biosafety manual for vector insectaries and infectories [20]. About 50 specimens of the parental generation were cryopreserved for the creation of a DNA bank for future genetic analyses. Only male mosquitoes were cryopreserved, eliminating the need to extract the female's abdomen to prevent possible DNA amplification from spermatozoa present in their spermateca. The Rockefeller [21] reference strain concerning insecticide susceptibility and vigor under laboratory conditions was employed for the determination of diagnostic-doses (DD), and was exposed in parallel in each assay, as an assay quality control. Standardizations of the biological tests performed on both adults and larvae were carried out using this susceptible strain.

\section{DD estimations}

Before the susceptibility evaluations of field Ae. aegypti populations, the DD for pyriproxyfen and malathion were estimated, respectively, in larvae and adults, under our local conditions. It is important to note that a WHO reference for a pyriproxyfen DD is still not available so far. The locally established DDs were obtained by doseresponse (DR) assays using the Rockefeller strain. The Rockefeller colony maintained at the LEnA was used for the tests in both laboratories.

\section{DD estimation for pyriproxyfen}

Larval bioassays were conducted with an IGR pyriproxyfen analytical standard (Sigma-Aldrich, Co., St Louis, USA), pre-dissolved in acetone (Sigma-Aldrich) and further diluted in ethanol (Merck, CGaA, Darmstadt, Germany). Following procedures described in the WHO guidelines for larvicide bioassays, with some modifications [22], third-stage larvae (L3 stage) were submitted to a gradient of 13 product concentrations ( 0.0667 to $0.2337 \mu \mathrm{g} / \mathrm{l}$ ), where adult emergence inhibition (EI) percentages were evaluated at the end of 7 to 10 days, when all control larvae had emerged into adults. Four replicates comprising 10 L3 larvae each were prepared for each concentration, and an equal number of controls were prepared using only ethanol. The larvae were fed $10 \mathrm{mg}$ of fish food (TetraMin ${ }^{\circledR}$, Tetra Marine Granules) on the first day and $5 \mathrm{mg}$ on the third day after initial exposure. The assays were followed daily until complete adult emergence in the control group.

Assays were discarded if the EI of the control group was $>10 \%$. If not, they were corrected using the Abbott's formula when EI ranged between 5\% and 10\% [22]. Four tests were performed at different times. When pupae began to develop, cups were covered with a mesh to avoid eventual adult escapes. Mortality and adult emergence were recorded when all the specimens under the control condition had emerged. Live adults were considered as those totally free of their exuviae and able to fly when gently touched, and the other individuals were considered dead. The EI were calculated using Probit (Polo-PC, LeOra Software, Berkeley, CA, USA) and logistic regression analyses [23]. Finally, the pyriproxyfen DD was determined as twice the dose that inhibited the emergence of adults in $99 \%\left(\mathrm{EI}_{99}\right)$ of Rockefeller larvae exposed to the compound.

\section{DD estimation for malathion}

To perform the bioassays, aliquots of OP stock solutions at a concentration of $3000 \mathrm{mg} / \mathrm{l}$ were prepared from a malathion analytical standard (Sigma-Aldrich) dissolved in acetone (Sigma-Aldrich) and stored at $-80{ }^{\circ} \mathrm{C}$. Glass bottles $(250 \mathrm{ml})$ (Wheaton) were coated on the inside with $1 \mathrm{ml}$ of malathion dissolved in acetone at four concentrations $(12,15,18$ and $20 \mu \mathrm{g} / \mathrm{bot}-$ tle) prepared from the stock solution $24 \mathrm{~h}$ before the test. Two bottles per concentration and one control (coated on the inside with $1 \mathrm{ml}$ of acetone only) were employed for each test, with each bottle containing 25 females aged 3-5 days-old. Six tests with each dose were performed, on distinct days. Mosquitoes were exposed to the insecticide for up to $30 \mathrm{~min}$, and mortality rates were recorded every $10 \mathrm{~min}$. The dose that caused $100 \%$ mortality in $30 \mathrm{~min}$ was considered as the 
Table 1 Brazilian towns participating in the 2017-2018 Aedes aegypti pyriproxyfen and malathion monitoring susceptibility round

\begin{tabular}{|c|c|c|c|c|c|c|c|c|c|}
\hline No. & Lat $^{a}$ & Long $^{b}$ & State & Town & No & Lat $^{a}$ & Long $^{b}$ & State & Town \\
\hline 1 & -7.36 & -72.67 & $A C$ & Cruzeiro do Sul & 74 & -13.54 & -48.22 & GO & Minaçu \\
\hline 2 & -9.98 & -67.81 & $A C$ & $\underline{\text { Rio Branco }}$ & 75 & -14.09 & -46.36 & $\mathrm{GO}$ & Posse \\
\hline 3 & -11.02 & -68.75 & $A C$ & Brasiléia & 76 & -16.77 & -47.61 & GO & Cristalina \\
\hline 4 & -2.63 & -56.74 & AM & Parintins & 77 & -16.67 & -49.26 & $\mathrm{GO}$ & $\underline{\text { Goiânia }}$ \\
\hline 5 & -0.14 & -67.08 & AM & São Gabriel da Cachoeira & 78 & -16.44 & -51.12 & $\mathrm{GO}$ & Iporá \\
\hline 6 & -7.51 & -63.03 & AM & Humaitá & 79 & -17.89 & -51.72 & $\mathrm{GO}$ & Jataí \\
\hline 7 & -4.23 & -69.95 & AM & Tabatinga & 80 & -17.74 & -49.11 & $\mathrm{GO}$ & Morrinhos \\
\hline 8 & -4.08 & -63.14 & AM & Coari & 81 & -19.01 & -57.65 & MS & Corumbá \\
\hline 9 & -3.13 & -60.02 & AM & Manaus & 82 & -22.23 & -54.81 & MS & Dourados \\
\hline 10 & 0.04 & -51.06 & AP & Macapá & 83 & -20.79 & -51.71 & MS & Três Lagoas \\
\hline 11 & 3.85 & -51.83 & AP & Oiapoque & 84 & -18.51 & -54.76 & MS & Coxim \\
\hline 12 & 2.50 & -50.94 & AP & Calçoene & 85 & -22.49 & -55.71 & MS & Ponta Porã \\
\hline 13 & -2.44 & -54.72 & PA & Santarém & 86 & -20.46 & -54.62 & MS & Campo Grande \\
\hline 14 & -7.10 & -49.94 & PA & Xinguara & 87 & -15.57 & -56.07 & MT & Cuiabá \\
\hline 15 & -1.46 & -48.49 & PA & Belém & 88 & -16.47 & -54.63 & MT & Rondonópolis \\
\hline 16 & -1.69 & -50.48 & PA & Breves & 89 & -10.64 & -51.57 & MT & Confresa \\
\hline 17 & -5.35 & -49.14 & PA & Marabá & 90 & -9.87 & -56.09 & MT & Alta Floresta \\
\hline 18 & -3.21 & -52.21 & PA & Altamira & 91 & -14.05 & -52.16 & MT & Água Boa \\
\hline 19 & -4.26 & -55.99 & PA & Itaituba & 92 & -15.23 & -59.34 & MT & Pontes e Lacerda \\
\hline 20 & -3.77 & -49.67 & PA & Tucuruí & 93 & -11.42 & -58.76 & MT & Juína \\
\hline 21 & -8.03 & -50.03 & PA & Redenção & 94 & -15.89 & -52.26 & MT & Barra do Garças \\
\hline 22 & -11.43 & -61.44 & $\mathrm{RO}$ & Cacoal & 95 & -11.86 & -55.50 & MT & Sinop \\
\hline 23 & -10.44 & -62.48 & $\mathrm{RO}$ & Jaru & 96 & -20.85 & -41.11 & ES & Cachoeiro do Itapemirim \\
\hline 24 & -8.77 & -63.83 & $\mathrm{RO}$ & Porto Velho & 97 & -20.32 & -40.32 & ES & Vitória \\
\hline 25 & -10.77 & -65.32 & $\mathrm{RO}$ & Guajará-Mirim & 98 & -18.71 & -40.40 & ES & Nova Venécia \\
\hline 26 & -12.74 & -60.14 & $\mathrm{RO}$ & Vilhena & 99 & -19.82 & -40.28 & ES & Aracruz \\
\hline 27 & 0.94 & -60.43 & $\mathrm{RR}$ & Rorainópolis & 100 & -23.01 & -44.32 & RJ & Angra dos Reis \\
\hline 28 & 2.82 & -60.67 & $\mathrm{RR}$ & Boa Vista & 101 & -21.75 & -41.33 & RJ & Campos dos Goytacazes \\
\hline 29 & -11.63 & -46.82 & TO & Dianópolis & 102 & -22.51 & -44.09 & RJ & Volta Redonda \\
\hline 30 & -10.16 & -48.35 & TO & $\underline{\text { Palmas }}$ & 103 & -22.88 & -43.23 & RJ & $\underline{\text { Rio de Janeiro }}$ \\
\hline 31 & -11.73 & -49.07 & TO & Gurupi & 104 & -19.94 & -43.93 & MG & Belo Horizonte \\
\hline 32 & -7.19 & -48.21 & TO & Araguaína & 105 & -18.85 & -41.95 & MG & Governador Valadares \\
\hline 33 & -9.66 & -35.70 & $A L$ & Maceió & 106 & -21.76 & -43.35 & MG & Juiz de Fora \\
\hline 34 & -9.76 & -36.66 & $\mathrm{AL}$ & Arapiraca & 107 & -16.72 & -43.87 & MG & Montes Claros \\
\hline 35 & -9.38 & -38.00 & $A L$ & Delmiro Gouveia & 108 & -19.71 & -47.98 & MG & Uberaba \\
\hline 36 & -11.30 & -41.86 & BA & Irecê & 109 & -17.86 & -41.51 & MG & Teófilo Otoni \\
\hline 37 & -13.01 & -38.49 & BA & $\underline{\text { Salvador }}$ & 110 & -19.53 & -42.62 & MG & Coronel Fabriciano \\
\hline 38 & -17.54 & -39.74 & BA & Teixeira de Freitas & 111 & -21.56 & -45.43 & MG & Varginha \\
\hline 39 & -14.79 & -39.27 & BA & Itabuna & 112 & -18.59 & -46.52 & MG & Patos de Minas \\
\hline 40 & -14.21 & -41.67 & BA & Brumado & 113 & -21.18 & -47.81 & SP & Ribeirão Preto \\
\hline 41 & -11.66 & -39.01 & BA & Serrinha & 114 & -22.12 & -51.39 & $\mathrm{SP}$ & Presidente Prudente \\
\hline 42 & -3.72 & -38.59 & CE & Fortaleza & 115 & -23.50 & -47.46 & SP & Sorocaba \\
\hline 43 & -3.69 & -40.35 & CE & Sobral & 116 & -20.81 & -49.38 & SP & São José do Rio Preto \\
\hline 44 & -5.18 & -40.67 & CE & Crateús & 117 & -23.81 & -45.40 & SP & São Sebastião \\
\hline 45 & -4.96 & -39.01 & CE & Quixadá & 118 & -23.57 & -46.57 & SP & $\underline{\text { São Paulo }}$ \\
\hline 46 & -6.40 & -38.86 & CE & Icó & 119 & -25.54 & -54.59 & PR & Foz do Iguaçu \\
\hline 47 & -7.21 & -39.32 & CE & Juazeiro do Norte & 120 & -23.31 & -51.16 & $P R$ & Londrina \\
\hline 48 & -6.76 & -38.23 & PB & Sousa & 121 & -23.08 & -52.46 & $P R$ & Paranavaí \\
\hline 49 & -7.15 & -34.87 & $\mathrm{~PB}$ & João Pessoa & 122 & -23.42 & -51.94 & $P R$ & Maringá \\
\hline
\end{tabular}


Table 1 (continued)

\begin{tabular}{|c|c|c|c|c|c|c|c|c|c|}
\hline No. & Lat $^{\mathrm{a}}$ & Long $^{b}$ & State & Town & No & Lat $^{\mathrm{a}}$ & Long $^{b}$ & State & Town \\
\hline 50 & -7.22 & -35.88 & PB & Campina Grande & 123 & -26.08 & -53.06 & $P R$ & Francisco Beltrão \\
\hline 51 & -7.04 & -35.63 & PB & Alagoa Grande & 124 & -27.87 & -54.48 & RS & Santa Rosa \\
\hline 52 & -8.06 & -34.89 & PE & $\underline{\text { Recife }}$ & 125 & -29.95 & -50.99 & RS & Gravataí \\
\hline 53 & -8.07 & -39.12 & PE & Salgueiro & 126 & -28.26 & -52.41 & RS & Passo Fundo \\
\hline 54 & -8.89 & -36.49 & PE & Garanhuns & 127 & -29.69 & -53.81 & RS & Santa Maria \\
\hline 55 & -9.40 & -40.50 & $P E$ & Petrolina & 128 & -30.38 & -56.45 & RS & Quaraí \\
\hline 56 & -8.68 & -35.59 & PE & Palmares & 129 & -26.73 & -53.52 & SC & São Miguel do Oeste \\
\hline 57 & -7.58 & -40.50 & PE & Araripina & 130 & -26.87 & -52.40 & SC & Xanxerê \\
\hline 58 & -7.96 & -36.20 & PE & Santa Cruz do Capibaribe & 131 & -26.91 & -48.66 & SC & Itajaí \\
\hline 59 & -6.77 & -43.02 & $\mathrm{Pl}$ & Floriano & 132 & -27.11 & -52.62 & SC & Chapecó \\
\hline 60 & -5.09 & -42.81 & $\mathrm{Pl}$ & Teresina & 133 & -10.94 & -69.56 & $A C$ & Assis Brasil \\
\hline 61 & -2.90 & -41.78 & PI & Parnaíba & 134 & -9.07 & -68.66 & $A C$ & Sena Madureira \\
\hline 62 & -7.08 & -41.47 & PI & Picos & 135 & 0.78 & -51.95 & AP & Pedra Branca do Amapari \\
\hline 63 & -9.02 & -42.69 & $\mathrm{Pl}$ & São Raimundo Nonato & 136 & -0.86 & -52.54 & AP & Laranjal do Jari \\
\hline 64 & -5.75 & -35.25 & $\mathrm{RN}$ & $\underline{\text { Natal }}$ & 137 & -9.37 & -37.25 & $A L$ & Santana do Ipanema \\
\hline 65 & -6.11 & -38.20 & RN & Pau dos Ferros & 138 & -12.14 & -45.00 & BA & Barreiras \\
\hline 66 & -6.59 & -36.77 & $\mathrm{RN}$ & Jardim do Seridó & 139 & -4.57 & -37.77 & CE & Aracati \\
\hline 67 & -5.19 & -37.36 & $\mathrm{RN}$ & Mossoró & 140 & -4.23 & -44.78 & MA & Bacabal \\
\hline 68 & -2.53 & -44.30 & MA & $\underline{\text { São Luís }}$ & 141 & -7.53 & -46.04 & MA & Balsas \\
\hline 69 & -10.91 & -37.05 & SE & Aracaju & 142 & -5.51 & -45.24 & MA & Barra do Corda \\
\hline 70 & -10.22 & -37.42 & SE & Nossa Senhora da Glória & 143 & -5.53 & -47.48 & MA & Imperatriz \\
\hline 71 & -10.69 & -37.43 & SE & Itabaiana & 144 & -22.29 & -42.53 & RJ & Nova Friburgo \\
\hline 72 & -10.92 & -37.67 & SE & Lagarto & 145 & -17.22 & -46.88 & MG & Paracatu \\
\hline 73 & -15.79 & -47.89 & DF & $\underline{\text { Brasília }}$ & 146 & -27.59 & -48.55 & SC & Florianópolis \\
\hline
\end{tabular}

a Latitude

b Longitude

Note: State capitals underlined. State acronyms: AC, Acre; AM, Amazonas; AP, Amapá; PA, Pará; RO, Rondônia; RR, Roraima; TO, Tocantins; AL, Alagoas; BA, Bahia; CE, Ceará; PB, Paraíba; PE, Pernambuco; PI, Piauí; RN, Rio Grande do Norte; MA, Maranhão; SE, Sergipe; DF, Distrito Federal; GO, Goiás; MS, Mato Grosso do Sul; ES, Espírito Santo; RJ, Rio de Janeiro; MG, Minas Gerais; SP, São Paulo; PR, Paraná; RS, Rio Grande do Sul; SC, Santa Catarina

DD, as recommended by the WHO [22]. The DD tests with field populations consisted of 25 females aged 3 to 5 days old gently blown with a Castor aspirator inside the bottles: 4 bottles coated with the malathion DD and 2 controls coated with acetone only. Addition tests were conducted applying the WHO recommended DD (50 $\mu \mathrm{g} /$ bottle) [24]. Three independent assays were performed for each population and using both laboratorydetermined and WHO recommended DDs.

\section{Evaluation of pyriproxyfen susceptibility in field populations}

\section{First screening with $D D$}

Once DD of the pyriproxyfen was obtained, larvae from each field population (16 replicates of 10 larvae, totaling 160 larvae) were exposed to the IGR DD, while 80 larvae from the same population (8 replicates of 10 larvae) were used as the negative control (ethanol only). In parallel, 80 Rockefeller larvae (8 replicates of 10 larvae) were also exposed to the $\mathrm{DD}$, as the internal control of assay conditions. Only healthy larvae exhibiting normal movement and from the same breeding site were selected for each test. The IGR solutions were prepared from a pyriproxyfen analytical standard (Sigma-Aldrich) predissolved in acetone (Sigma-Aldrich) and further diluted in ethanol $\left(\operatorname{Merck}^{\circledR}\right)$. Aliquots containing $15 \mu \mathrm{l}$ of the IGR at a concentration of $100,000 \mathrm{mg} / \mathrm{l}$ were prepared and stored at $-80{ }^{\circ} \mathrm{C}$. These aliquots were then used to prepare $5 \mathrm{ml}$ stock solutions at a concentration of 300 $\mathrm{mg} / \mathrm{l}$ and were stored in a refrigerator for up to 30 days. A new dilution was prepared on the same day of the tests from these stock solutions, at a final concentration from which $1 \mathrm{ml}$ would result in the desired DD in the $250 \mathrm{ml}$ test cups. Each population was tested four independent times. The EI of each population was established as the means of these four assays. A total of 240 larvae from the evaluated field population (including their replicates) were necessary for each dose-diagnostic test, totaling 960 larvae in the four repetitions performed in different rounds. WHO criteria were applied to classify the 


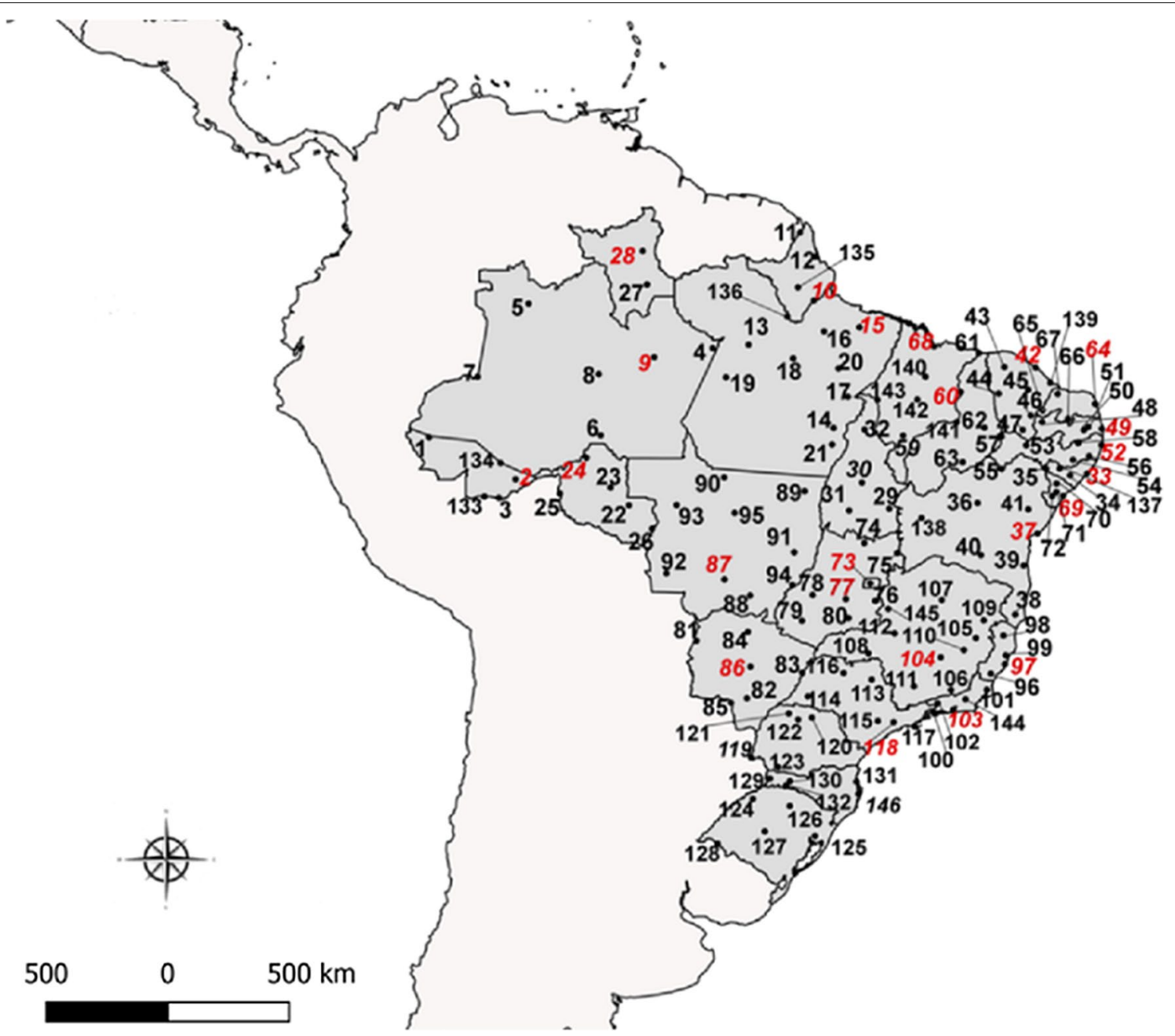

Fig. 1 Map of Brazil showing the municipalities participating in the 2017-2018 Aedes aegypti pyriproxyfen and malathion susceptibility monitoring round. The numbers in red represent state capitals. The continuous lines in Brazilian territory indicate different states

populations as susceptible, exhibiting suggested resistance or resistant, when EI were $\geq 98 \%$, between 90 and $97.9 \%$ and $<90 \%$, respectively [22].

\section{Resistance ratio estimation}

Field populations not susceptible to pyriproxyfen (EI < $98 \%$ ) in DD assays were submitted to a DR assay in order to quantify their resistance levels. Larvae were exposed to a range of 10 concentrations $(0.008-0.45 \mu \mathrm{g} / \mathrm{l})$ in four replicates comprising $10 \mathrm{~L} 3$ larvae each and four control replicates using ethanol only. The Rockefeller strain was run in parallel, consisting of four replicates, with larvae exposed to the DD only. Mortality and metamorphosis rates were recorded until the emergence of all adults in the control condition. A total of 440 larvae were evaluated in each DR test, including their replicates, requiring 1760 larvae from each field population to perform the repetitions of the four different rounds.
The inhibition of $50 \%$ and $95 \%$ adult emergence $\left(\mathrm{EI}_{50}\right.$ and $\mathrm{EI}_{95}$ ) of each population were obtained by a probit analysis [25]. Resistance ratios were obtained by dividing the EI (50 and 95) of each population by the equivalent EI of the Rockefeller reference strain. Populations were classified as suggested by Mazzarri \& Georghiou [26] into low, moderate, or high resistance respectively for $\mathrm{RR}_{95}<$ 5 , between $5.0-10.0$, and $>10.0$.

\section{Evaluation of malathion susceptibility in field populations}

The Ae. aegypti populations were tested using adult females, 3 to 5 days post-emergence and not blood-fed, from the F1 or F2 generations. Each test consisted of the exposure of 20 to 25 females per bottle, with 4 bottles coated on the inside with each DD (the DD evaluated herein and $50 \mu \mathrm{g} /$ bottle) in addition to 2 bottles coated on the inside with acetone only as the negative control. The reference Rockefeller strain was run in parallel with 
2 bottles coated with each DD. Mortality rates were recorded every $15 \mathrm{~min}$, and mosquitoes that could not stand, were considered dead. Mortality rates for the replicates of each DD were calculated at the diagnosis time (30 min) in each assay. A total of 4 bioassays were performed for each population, and the final result considered the mean mortality of these bioassays. A total of 1000 females from each field population were used to carry out four different rounds of these tests, comprising 250 females in each, including replicates.

The DD and DR assays for both the IGR and adulticide compounds were performed under test-insectary conditions, with controlled temperature $\left(26 \pm 2{ }^{\circ} \mathrm{C}\right)$ and humidity $(70 \pm 10 \%)$.

\section{Data analysis}

The percentages of adult emergence inhibition, lethal doses (LD), their respective confidence intervals (95\% $\mathrm{CI}$ ) and the population slope were calculated by the PoloPC software, employing a probit analysis [25]. Resistance ratios (RR) were obtained by the quotient between the LD of a population by the Rockefeller reference strain values. Maps were constructed using the QGIZ version 2.18.6 and GIMP version 2.10.14 software packages [23].

\section{Results}

A total of 146 urban Brazilian cities were selected to evaluate $A e$. aegypti susceptibility/resistance to insecticides current employed in official national campaigns throughout the country (Table 1, Fig. 1), based on a geographical representation proposal. State capitals, international borders and cities exhibiting previous insecticide resistance data were preferentially selected. Appropriate egg sampling was performed in 140 (95.9\%) localities. Eggs from 14 (9.6\%), however, did not hatch or the number of resulting larvae were insufficient to produce a F1 generation (less than 100 females). Thus, new samplings were carried out in a further six (4.1\%) localities. Female numbers remained low even after a second collection and F1 Ae. aegypti colonies were raised with less than 100 F0 females for four localities, namely Parintins (Amazonas), Irecê (Bahia), Quixadá (Ceará) and Salgueiro (Pernambuco). A total of 132 Ae. aegypti populations $(94.3 \%$ of the initially planned point collections) were evaluated. The number of Ae. aegypti mosquitoes obtained per population ranged from 48 to 2438 females and from 54 to 2563 males. Aedes albopictus was present in $59.8 \%(78 / 132)$ of the populations, at $1-419$ females and 1-455 male ratios.

Table 2 presents information regarding the geographical origin, number of total and positive paddles (paddles containing eggs), mean egg numbers in positive paddles, total resulting adults for both Ae. aegypti and Ae. albopictus, adult emergence inhibition (EI) to the IGR larvicide and mortality after exposure to the adulticide organophosphate.

The dose-diagnostic (DD) obtained for pyriproxyfen was of $0.015 \mu \mathrm{g} / \mathrm{l}$ (Table 3). Among the 132 evaluated populations, six $(4.5 \%)$ from the Brazilian northeastern cities of Itabuna, Brumado and Serrinha (Bahia), Quixadá, Icó, and Juazeiro do Norte (Ceará), presented EI < $98 \%$, thus being subjected to DR tests to assess resistance levels (Table 2, Fig. 2). Resistance ratios $\left(R_{50}\right.$ and $\left.R R_{95}\right)$ were low in these populations, ranging between 1.07$1.97\left(R_{50}\right)$ or $1.51-3.58\left(R_{95}\right)$ (Table 4$)$, indicating low resistance. Approximately 137,280 larvae were tested to perform all dose-diagnostic larval assays for the 132 populations, followed by DR assays in six populations that did not exhibit pyriproxyfen susceptibility.

The DD obtained for malathion under our laboratory conditions was of $20 \mu \mathrm{g} /$ bottle (Fig. 3), 2.5-fold lower than the established WHO value $(50 \mu \mathrm{g} /$ bottle). In the $20 \mu \mathrm{g} /$ bottle DD tests (Fig. 4a), 28 populations (21.4\%) presented mortality above 98\% (susceptible), 30 (22.9\%) exhibited mortality between 90 and $98 \%$ (suggested resistance) and 73 populations (55.7\%) displayed mortality below $90 \%$ (confirmed resistance). On the other hand, when exposed to $50 \mu \mathrm{g} / \mathrm{bottle}$ (Fig. 4b), most of the populations $(121,92.4 \%)$ were considered susceptible, and the remaining (10, 7.6\%), as presenting "suggested resistance", with mortality rates ranging from 90 and $98 \%$. Approximately 131,000 Ae. aegypti female adults from 131 field populations were required for the malathion susceptibility testing. As noted in the map displayed in Fig. 4a, although localities with populations where resistance to $20 \mu \mathrm{g} / \mathrm{bot}-$ tle malathion was suggested are spread out throughout the country, the north region concentrates the highest percentage of resistant populations (71.9\%).

\section{Discussion}

The present study evidenced the feasibility of conducting an insecticide resistance monitoring action in a standardized and strongly coordinated manner, applying a model that may be of assistance in implementing national monitoring plans in other countries. A systematic literature review covering insecticide resistance data in Ae. aegypti field populations from Latin America and the Caribbean indicates that less than half of the countries in this region have published bioassay data between 2008 and 2018 [7]. In addition, the number of populations representing each national surveillance was generally rather low [7]. Susceptibility monitoring to temephos and deltamethrin carried out between 1999 and 2011 by the previous "National Network for Monitoring the Resistance of Ae. aegypti to Insecticides" generally evaluated between 25 and 74 populations every two years [17]. 
Out of all Ae. aegypti populations evaluated herein, $99.3 \%$ were classified as susceptible to the IGR pyriproxyfen. The six resistant populations were from the same geographical region (Northeast), in the states of Bahia (Itabuna, Brumado and Serrinha) and Ceará (Quixadá, Icó and Juazeiro do Norte), suggesting the emergence of localized pyriproxyfen resistance. Interestingly, some of these populations exhibited discrepant $R_{50}$ and $R R_{95}$ values, suggesting a heterogeneous response within the population, as represented by low slope values (Table 4). These populations are likely experiencing an initial selection process, where only some individuals exhibit resistance so far. We hypothesized that this regionalization is related to differences in operational applications and the amount of applied insecticides, as well as due to population genetic background peculiarities, although no evidence to support this so far is available. It is noteworthy that Ae. aegypti populations from the Northeast presented the highest levels of temephos resistance in Brazil [9], as well lower residual effects in field assays, noted in populations from localities where high temephos RRs were previously described [27]. These data were collected before the introduction of pyriproxyfen use, suggesting cross-resistance. In the case of Itabuna, in the state of Bahia, simulated field trials carried out in 2015 demonstrated $100 \%$ pyriproxyfen efficacy within 30 days after application, albeit with a significant drop in the EI after 45 days [28]. Further investigations are required in order to better understand the mechanisms related to this trend.

We evidenced that the lowest malathion concentration able to kill $100 \%$ of Rockefeller females in 30 min was 20 $\mu \mathrm{g} /$ bottle, a 2.5 -fold lower dose than that recommended by WHO in bottle assays $(50 \mu \mathrm{g})$ [24]. No malathionresistant populations (mortalities of less than 90\%) were observed when the WHO DD $50 \mu \mathrm{g} /$ bottle was employed, while 73 populations ( $55.8 \%$ of the total evaluated) were classified as resistant in the $20 \mu \mathrm{g} /$ bottle exposure assays. The WHO-suggested DD is based on tests performed in reference laboratories and estimated from a variety of susceptible strains for resistance detection, seeking easy testing and reliability. This DD should be considered as a guide that may be refined for local situations whenever possible [29]. The local DD was more sensitive in the early discrimination of resistant individuals. This results in an interesting approach in identifying decreased susceptibility before reaching levels that may incur in loss of insecticide effectiveness in the field. The resistance monitoring programme in Brazil seeks to detect early susceptibility changes so that the applied product may be changed in a timely manner. Early detection would also permit management approaches enabling to more rapidly revert to the susceptible status of a population in cases where resistance is not so high.

The meaning of laboratory-observed resistance associated to product effectiveness under field conditions should be studied. Assessments conducted two decades ago had already reported Ae. aegypti resistance to malathion in northeastern Brazilian populations, when OPs were used to control both the larval (temephos) and adult (malathion) phases [17]. Insecticide selection against $A e$. aegypti in Brazil followed the WHO criteria, also indicating that a product should be replaced in areas with a high RR (> 10.0) and with confirmed lack of efficacy in simulated field tests [11]. However, insecticide substitution takes an average of two years [2], since it depends on series of bureaucratic processes. Therefore, the time spent between the first detection of resistance in a laboratory bioassay and the effective change of the compound in the field has not been effective in precluding the spread of insecticide resistance. In order to avoid decreased insecticide effectiveness in the field, a more sensitive replacement criterion has been adopted since 2006. In this regard, changing the active ingredient of the insecticide is recommended in localities where mosquito populations present mortality rates below $70 \%$ in DD assays or with $\mathrm{RR}_{95}>3.0$, which occurs before the previous applied management criteria, of mortality rates below $80 \%$ in DD assays and $\mathrm{RR}_{95}>10.0$ [11]. Results for the state of São Paulo were the basis for this arrangement, where simulated field trials with temephos demonstrated failures in the control of Ae. aegypti in populations exhibiting $\mathrm{RR}_{95}$ $>$ 3.0. PYs were ineffective in simulated field trials against populations with mortality rates below $70 \%$ in the DD in laboratory bioassays [30]. This was a very severe criterion, aiming to preserve resistance evolution or reverse it. Since no RR values $>5$ for pyriproxyfen are observed in the country, IGR use may be continued, although the best scenario would be to apply another insecticide class in locations presenting suggested resistance.

Concerning adulticides, the situation is alarming, since there is only one available alternative to PY and to the OP malathion, i.e. the association of prallethrin with imidacloprid [31]. In the most recent national evaluation concerning PYs (2011 and 2012) high RRs for deltamethrin were observed throughout the country [8]. In addition, localities with higher numbers of dengue incidence in São Paulo were also those exhibiting higher levels of PY resistance, although these compounds were no longer being applied by governmental campaigns against $A e$. aegypti. This is associated to the excessive use of insecticides in households, especially during arbovirus epidemic seasons, and PYs application against other urban vectors, as observed in an area where an intense campaign against 


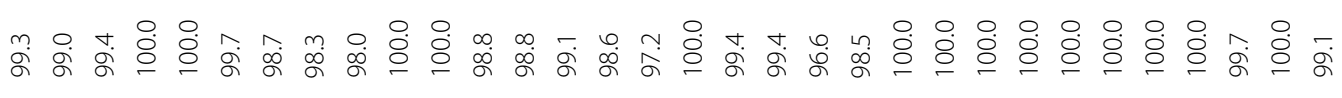

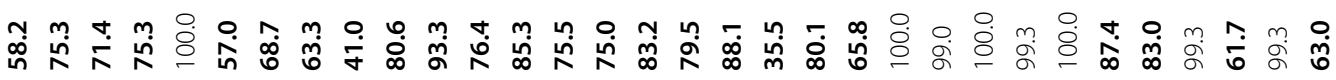

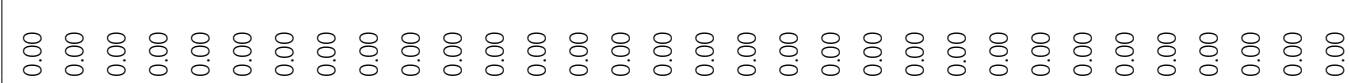

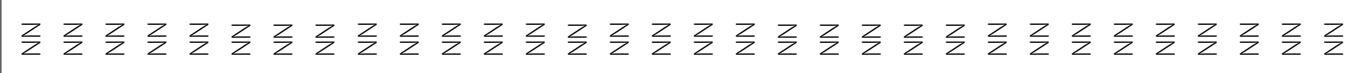

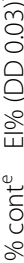

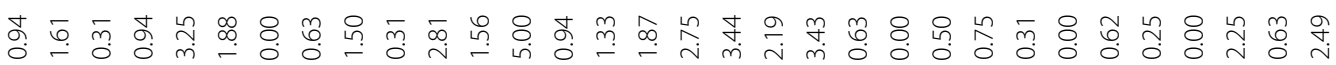

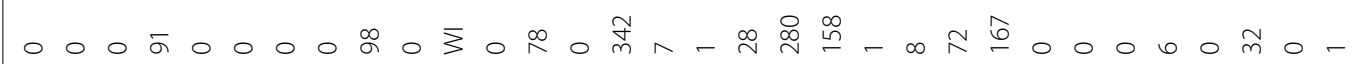

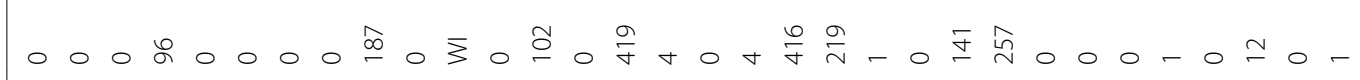

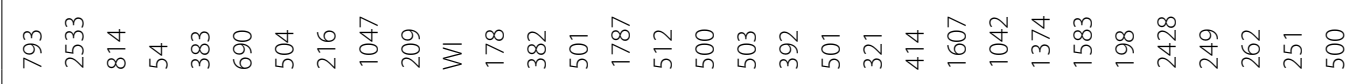

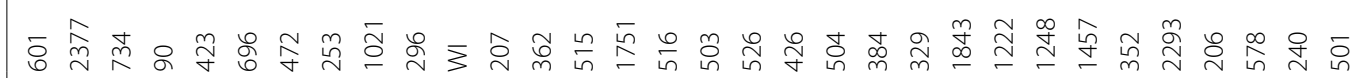

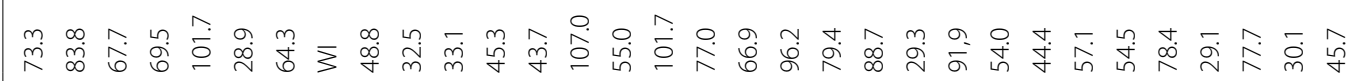

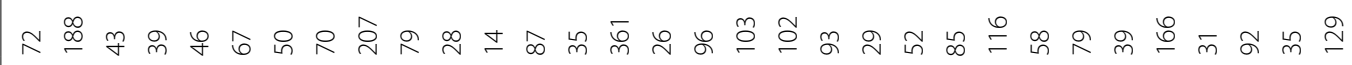

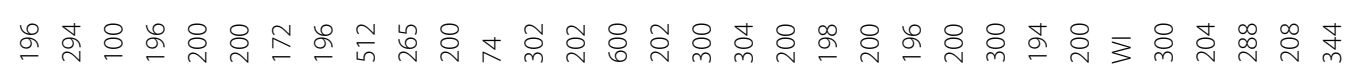

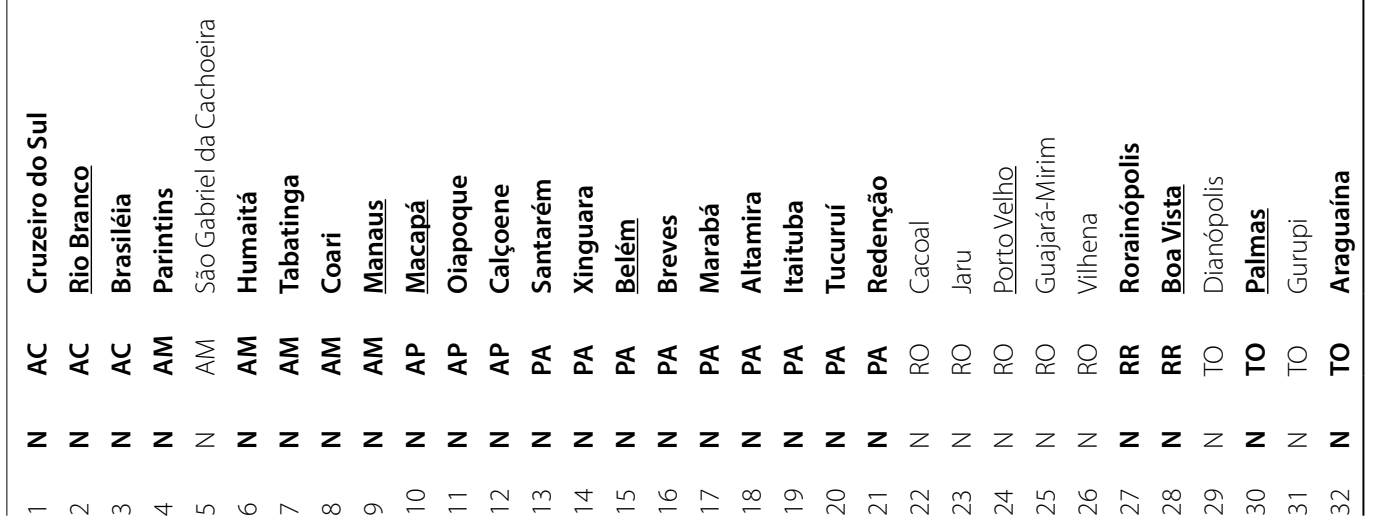




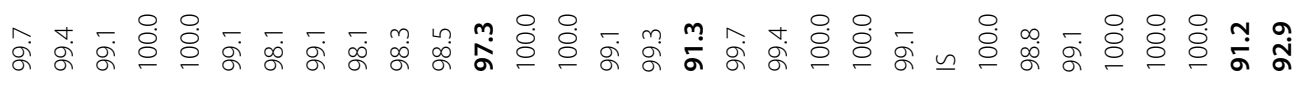

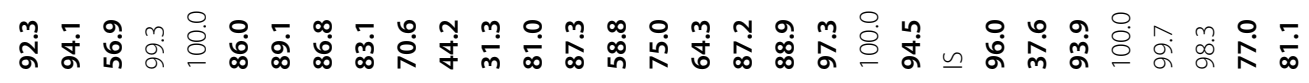
: 웅 : : : : : : :

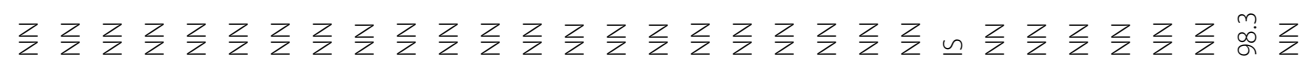

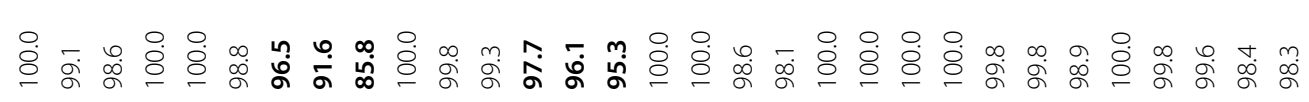

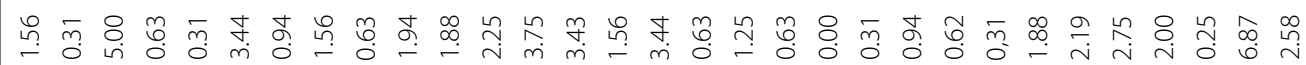
ก

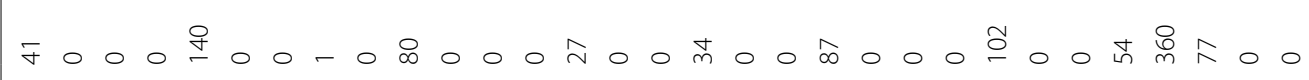

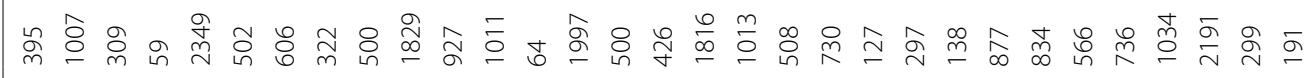

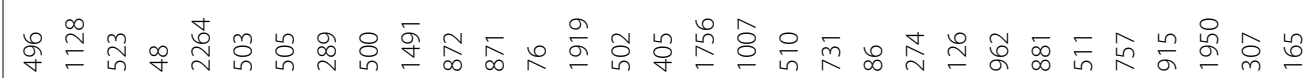

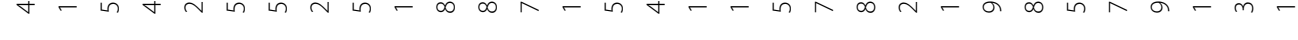




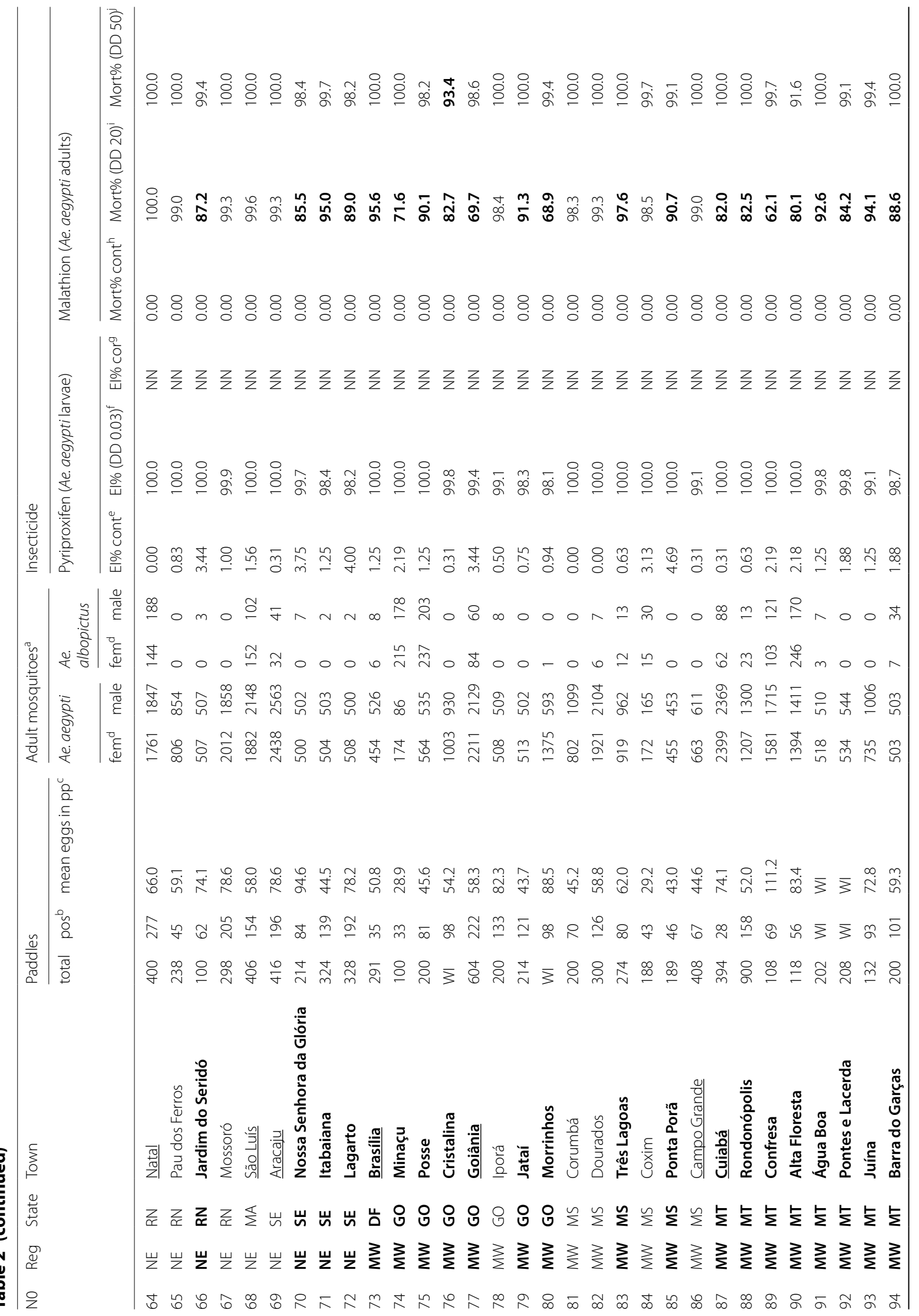


过 势

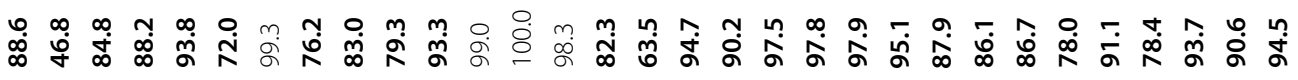

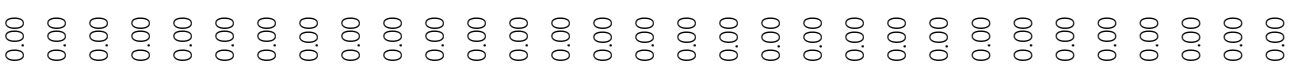

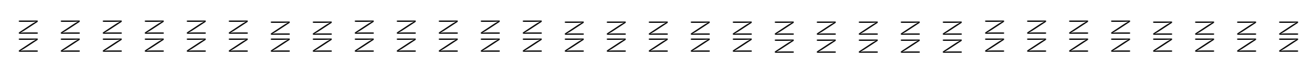
लิ

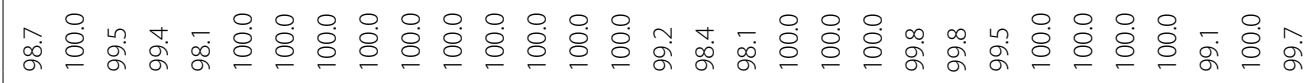

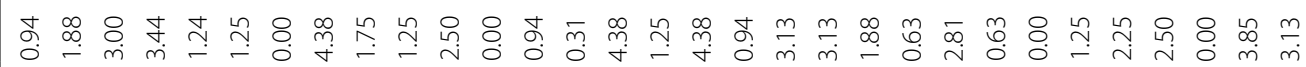

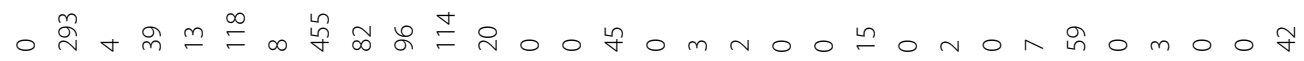

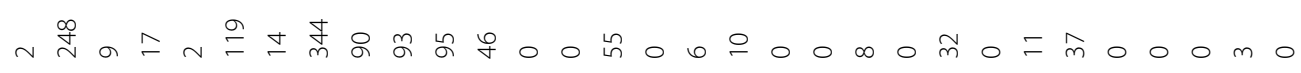

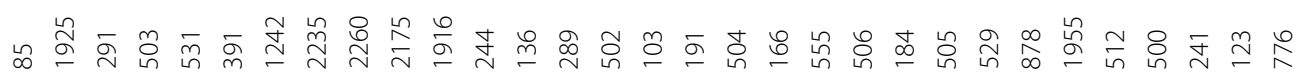

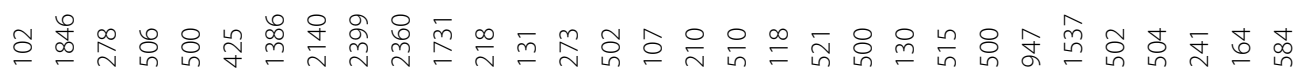

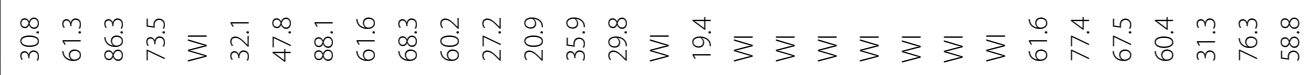

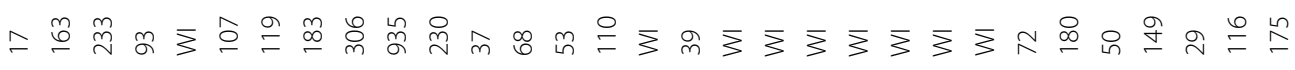

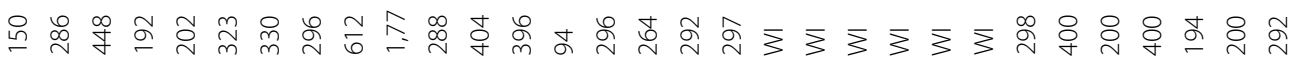

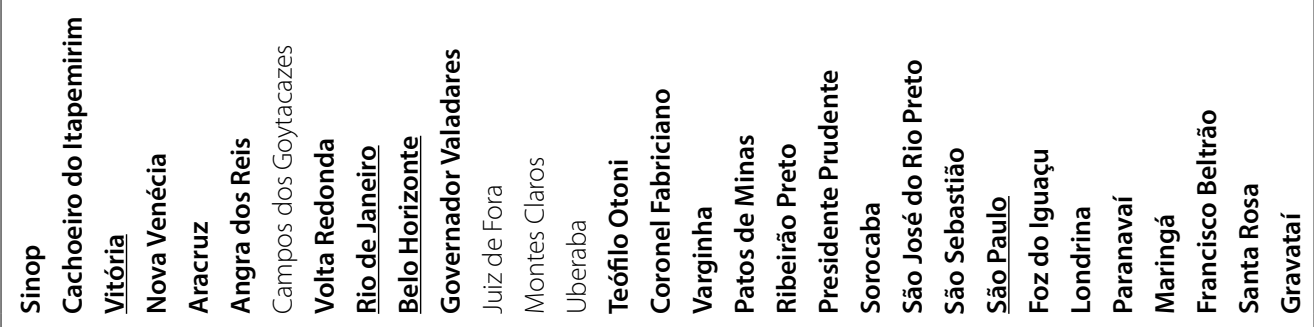

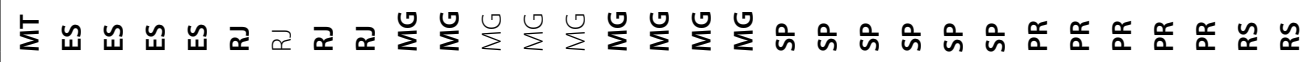

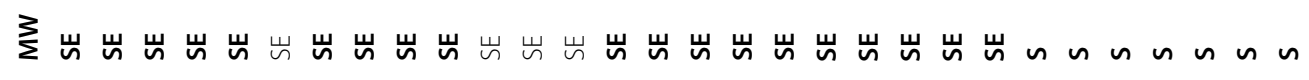

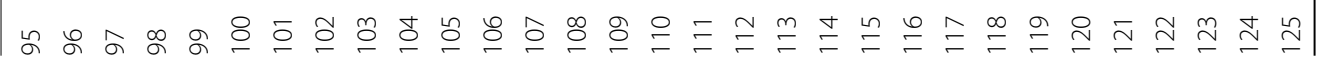




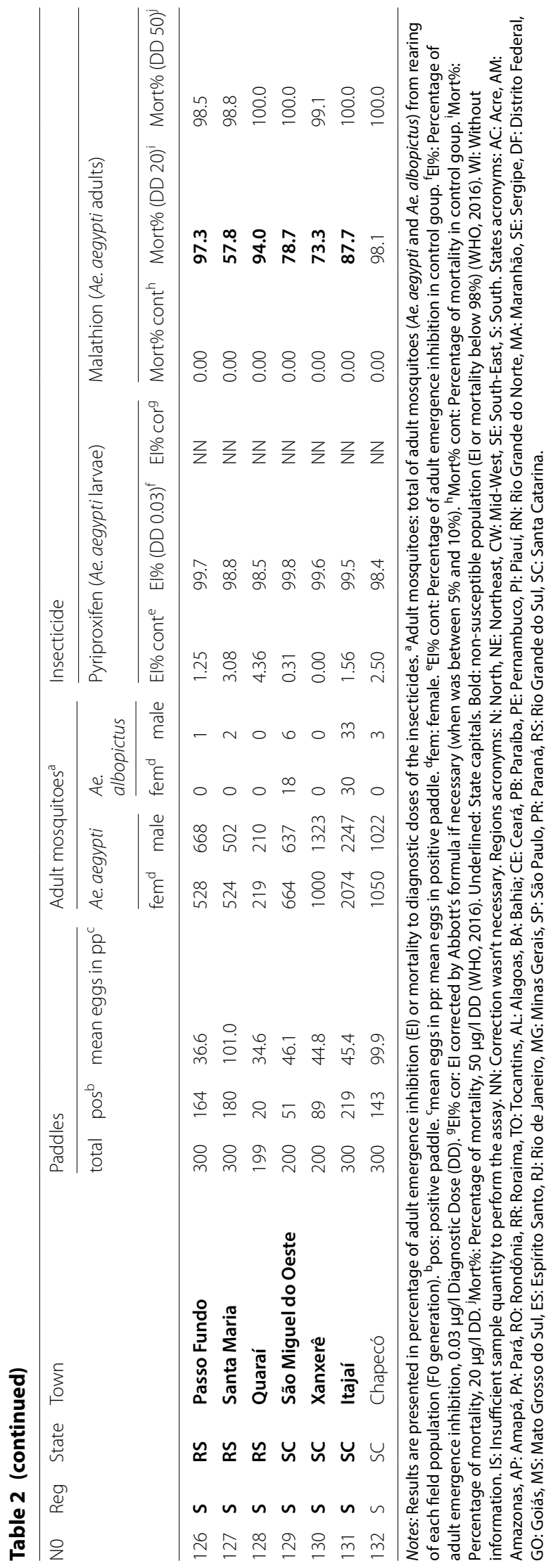

Table 3 Dose-response bioassay to determine the pyriproxyfen diagnostic dose for Aedes aegypti, Rockefeller strain

\begin{tabular}{lllll}
\hline $\mathrm{El}_{50}\left(\mu \mathrm{g} / \mathrm{l}^{\mathrm{a}}\right.$ & $\mathrm{Cl}_{50}\left(\mu \mathrm{g} / \mathrm{l}^{\mathrm{b}}\right.$ & $\mathrm{El}_{99}\left(\mu \mathrm{g} / \mathrm{l}^{\mathrm{a}}\right.$ & $\mathrm{Cl}_{99}\left(\mu \mathrm{g} / \mathrm{l}^{\mathrm{b}}\right.$ & Slope \\
\hline 0.06205 & $0.06012-0.06394$ & 0.15589 & $0.14655-0.16733$ & 5.8164
\end{tabular}

${ }^{\mathrm{a}} \mathrm{El}_{50}$ and $\mathrm{El}_{99}$ : pyriproxyfen concentrations needed to inhibition of $50 \%$ and $99 \%$ adults emergence, respectively

${ }^{b} \mathrm{Cl}$ : confidence intervals

Emerging resistance to all the main classes of neurotoxic insecticide (CA, OC, OP and PY) has been detected in Ae. aegypti from the Americas, Africa and Asia [33]. The occurrence of susceptibility alterations concerning IGR, the most recently adopted class of insecticides, reinforces the importance of using integrated tools that can contribute to reduce the need for chemical vector control, modifying arbovirus transmission determinants, such as sustainable environmental management and education actions [34]. Lesser use of chemical insecticides reduces the risk of associated factors, such as ecological imbalances, secondary pest outbreaks and harmful effects to human health and to other non-target animals [35].

An alert is required concerning the high frequency of populations also comprising Ae. albopictus (59.8\%). Our sampling was performed on the grounds of houses in urban territories, evidencing the significant expansion of this species in the country since its first record in 1986, in rural areas [36]. Further studies are recommended to better understand the role of Ae. albopictus in arbovirus transmissions in Brazil. In parallel, the monitoring of insecticide Ae. aegypti resistance should also consider Ae. albopictus populations.

Finally, the evaluation of all 146 planned populations was not possible, since some samplings were not carried out due to operational difficulties, while the laboratory maintenance of some populations was prevented by insufficient or inadequate egg preservation, hindering hatching. This limitation was minimized by providing the necessary material to all participants and preparing a video in order to standardize sampling and laboratory transport procedures.

\section{Conclusions}

The challenge posed by vector resistance to different active ingredients available for their chemical control reinforces the importance of implementing Integrated Management Strategies, which prioritize mechanical control and educational actions, with the aim of decreasing the number of breeding sites [1,2]. A wellstructured mosquito insecticide resistance monitoring system is essential for a sustainable, integrated and 


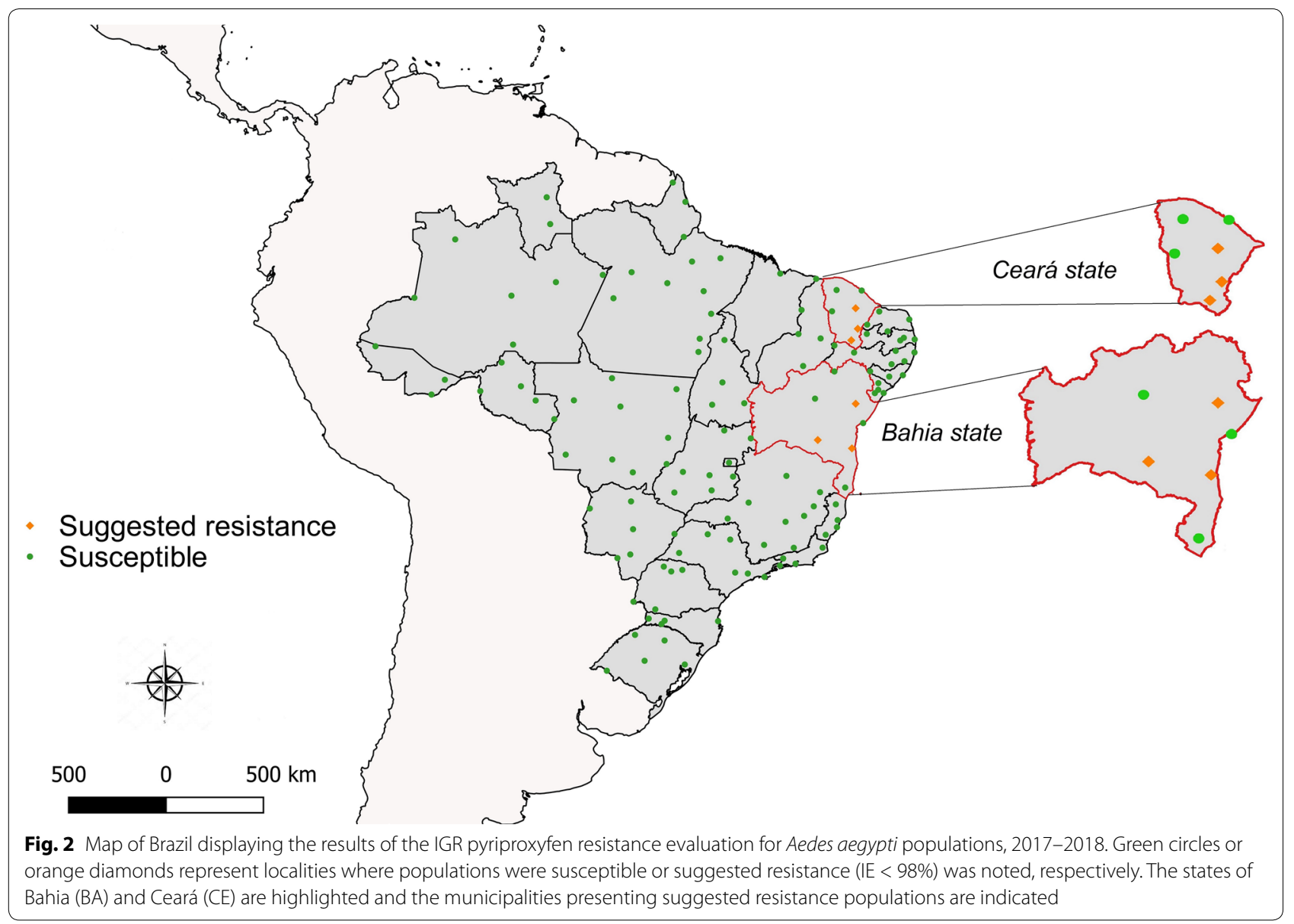

Table 4 Dose-response bioassays on Aedes aegypti populations resistant to pyriproxyfen in Brazil, 2017-2018

\begin{tabular}{|c|c|c|c|c|c|c|c|c|}
\hline Region & State & Population/City & $\mathrm{El}_{50}\left(\mu \mathrm{g} / \mathrm{I}^{\mathrm{a}}(\mathrm{Cl})\right.$ & $\mathrm{El}_{95}(\mu \mathrm{g} / \mathrm{l})^{\mathrm{a}}(\mathrm{Cl})$ & $\mathrm{RR}_{50} \mathrm{~b}^{\mathrm{b}}$ & $\mathrm{RR}_{95}{ }^{\mathrm{b}}$ & Slope & Resistance level ${ }^{c}$ \\
\hline & & Rockefeller & $0.0621(0.0620-0.0639)$ & $0.1190(0.1137-0.1253)$ & 1.00 & 1.00 & 5.81 & - \\
\hline \multirow[t]{6}{*}{ Northeast } & Bahia & Serrinha & $0.1207(0.0312-0.4665)$ & $0.4257(0.1711-1.0595)$ & 1.95 & 3.58 & 3,00 & Low \\
\hline & & Itabuna & $0.1223(0.0942-0.1588)$ & $0.4056(0.2776-0.5927)$ & 1.97 & 3.41 & 3.16 & Low \\
\hline & & Brumado & $0.0666(0.0510-0.0871)$ & $0.3160(0.2699-0.3699)$ & 1.07 & 2.66 & 2.43 & Low \\
\hline & Ceará & Juazeiro do Norte & $0.0835(0.0498-0.1399)$ & $0.2495(0.1884-0.3304)$ & 1.35 & 2.10 & 3.46 & Low \\
\hline & & Quixadá & $0.0900(0.0800-0.0900)$ & $0.2200(0.2000-0.2400)$ & 1.45 & 1.85 & 4.31 & Low \\
\hline & & Icó & $0.0700(0.0600-0.0800)$ & $0.1800(0.1500-0.2200)$ & 1.13 & 1.51 & 4.25 & Low \\
\hline
\end{tabular}

${ }^{\mathrm{a}} \mathrm{El}_{50}$ and $\mathrm{El}_{95}$ : inhibition of $50 \%$ and $95 \%$ adult emergence pyriproxyfen concentrations, respectively (Cl: confidence intervals)

${ }^{b} \mathrm{RR}_{50}$ and $\mathrm{RR}_{95}$ : resistance ratios

c Resitance level: $\mathrm{RR}_{95}<5.0$ : low; $\mathrm{RR}_{95}$ 5.0-10.0: moderate; $\mathrm{RR}_{95}>10.0$ : high Mazzarri \& Georghiou [26]

effective plan based on chemical vector control strategies. We described the sampling and standardization activities of insecticide resistance monitoring tests for Ae. aegypti from 132 Brazilian localities between 2017 and 2018, discussing their results in the light of knowledge acquired since the first monitoring round carried
Leishmania vectors was implemented [32]. The present study demonstrated resistance to malathion in most of the evaluated mosquito populations with the $20 \mu \mathrm{g} / \mathrm{bot}-$ tle DD. Therefore, chemical control against Ae. aegypti is crucially threatened in most Brazil territory, as long as no other alternative compound is available. 

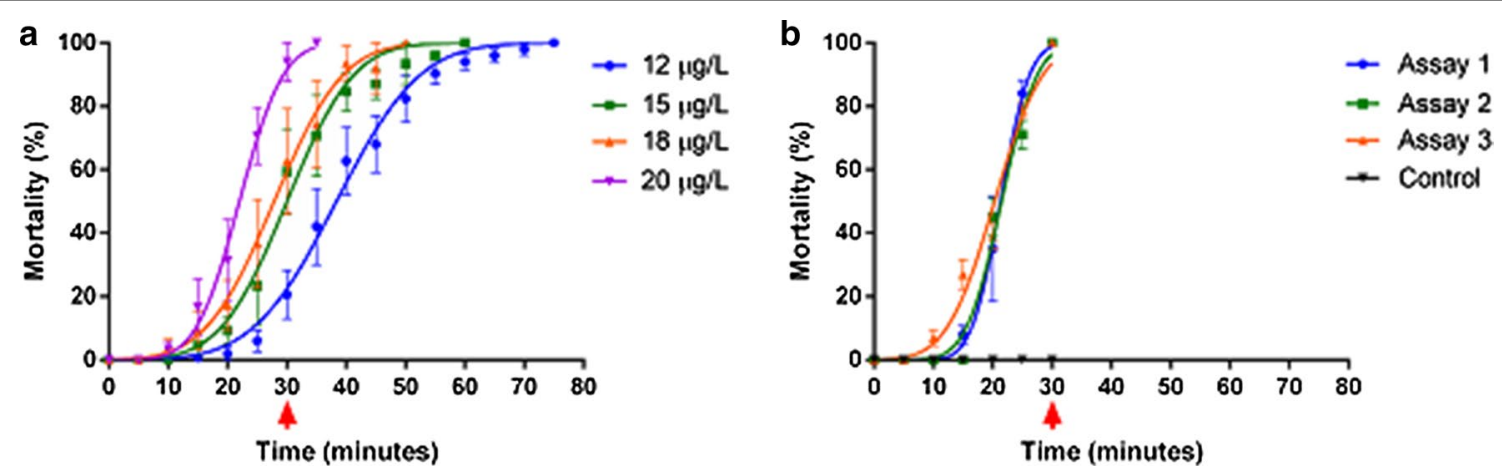

Fig. 3 Determination of the malathion diagnostic-dose (DD) in Aedes aegypti, Rockefeller strain. a Mortality throughout the exposure period to bottles coated inside with different doses. b Three additional independent trials with DD set at $20 \mu \mathrm{g} / \mathrm{ml}$, resulting in $100 \%$ mortality in 30 min. The red arrow highlights the 30 min mark

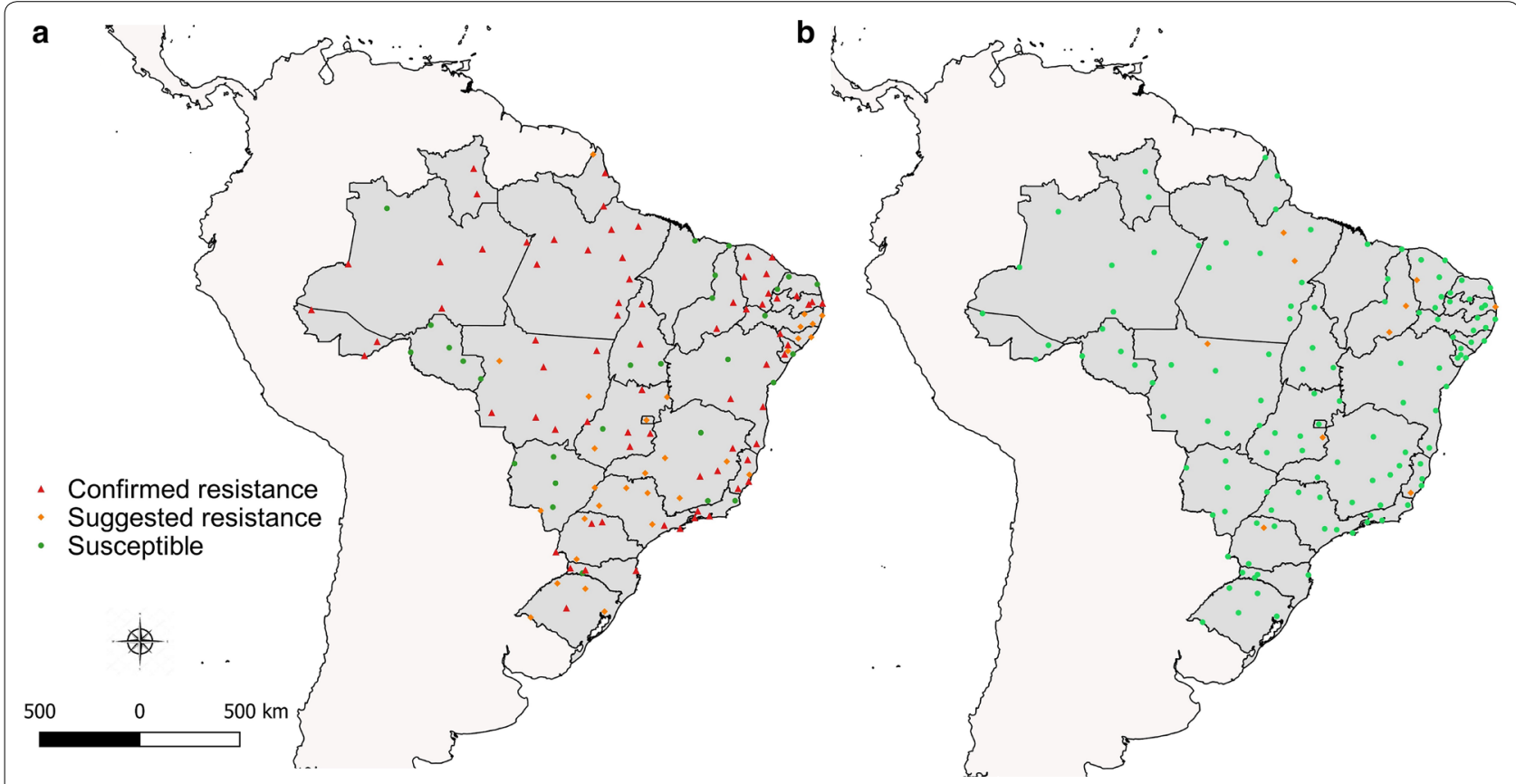

Fig. 4 Map of Brazil displaying the results of the organophosphate malathion resistance evaluation for Aedes aegypti populations, 2017-2018. Diagnostic-dose tests employed a $20 \mu \mathrm{g} /$ bottle (a) or $50 \mu \mathrm{g} /$ bottle dose (b). Green circles, orange diamonds or red triangles represent localities where populations were considered susceptible, with suggested resistance or with confirmed resistance, respectively

out in 1999. We currently recommend the substitution of pyriproxyfen for an alternative larvicide class in areas where susceptibility changes were detected, in order to preserve the efficacy of this IGR. Regarding adulticides, resistance to malathion was as widespread in all Brazilian regions through laboratory-based DD assessments. Therefore, an alternative class of insecticide should be used to control adult mosquitos, also considering the previously noted history of pyrethroid resistance in Brazil. Resistance monitoring and the evaluation of new products must be performed continuously in locations that represent Brazil's geographical, climatic and urban diversity.

\section{Abbreviations}

BPU: Benzo-phenyl urea; Bti: Bacillus thurigiensis; CA: Carbamate; CDC: Centers for Disease Control and Prevention; DD: Diagnostic dose; DR: Dose-response; El: Adult emergence inhibition; F1: First generation; F2: Second generation; FIOCRUZ: Oswaldo Cruz Foundation; IGR: Insect growth regulator; IOC: Oswaldo Cruz Institute; IR: Insecticide resistance; LAFICAVE: Laboratory of Physiology and Arthropod Control Vectors; LD: Lethal dose; LEnA: Laboratory of Applied Entomology; MoH: Ministry of Health; MoReNAa: National Network for Monitoring the Resistance of Aedes aegypti to Insecticides; PNCD: National 
Dengue Control Program; OP: Organophosphate; PY: Pyrethroid; RIDL: Release of insects with dominant lethality; RR: Resistance ratio; SIT: Sterile insect technique; SUCEN: Endemic Control Superintendence; WHO: World Health Organization; WP: Wettable powder.

\section{Acknowledgments}

The authors wish to thank the municipal teams involved in the bioassay sample collections, the coordination state teams, the laboratory teams that conducted the tests and the Ministry of Health for making the data available for this study.

\section{Authors' contributions}

$J B P L$ and $K B C$ performed the conceptualization and funding acquisition. JBPL, MLGM and MTMA provided supervision. KBC wrote an original draft of the manuscript. DFB provided formal analysis and methodology. JBPL and CMR conducted project administration. CMR and DFB provided quality management. MTO, JBPL, MLGM, MTMA, AJM, DFB, CMR and LSD were involved in writing, review and editing the manuscript. All authors read and approved the final manuscript.

\section{Funding}

General Coordination of Arboviruses Surveillance/Ministry of Health (Brasília, DF, Brazil) provided financial support for the survey through Agreement/TED/Commitment Term No. 105/2016 (National Health Fund), process number 25030,000852/2016-46. The Oswaldo Cruz Foundation provided funding for the publication. The funders had no role in the design of the study, data collection and analysis, decision to publish or preparation of the manuscript.

\section{Availability of data and materials}

Data supporting the conclusions of this article are included within the article. The datasets required to reproduce the analyses and results presented herein are available from the corresponding author upon reasonable request.

\section{Ethics approval and consent to participate}

Artificial feeding of Ae. aegypti authorized by the Fiocruz Ethics Committee on the Use of Animals (authorizations LW-20/14 and L-004/2018).

\section{Consent for publication}

Not applicable.

\section{Competing interests}

The authors declare that they have no competing interests.

\section{Author details}

${ }^{1}$ Coordenação Geral de Vigilância de Aboviroses, Secretaria de Vigilância em Saúde, Ministério da Saúde, Edifício PO 700, SRTV 702, Via W 5 Norte, Brasília/ Distrito Federal CEP 70723-040, Brazil. ${ }^{2}$ Laboratório de Parasitologia Médica e Biologia de Vetores, Faculdade de Medicina, Universidade de Brasília, Campus Universitário Darcy Ribeiro, Asa Norte, Brasília/Distrito Federal CEP 70910-900, Brazil. ${ }^{3}$ Laboratório de Fisiologia e Controle de Artrópodes Vetores, Instituto Oswaldo Cruz, Rua Francisco Manuel no 102, Bairro Benfica, Rio de Janeiro/Rio de Janeiro State CEP 20911-270, Brasil. ${ }^{4}$ Laboratório de Entomologia Aplicada, Superintendência de Controle de Endemias, Secretaria de Estado da Saúde de São Paulo, Avenida Santo Antônio no 1627, Bairro Somenzari, Marília/São Paulo CEP 17506-970, Brasil.

Received: 6 July 2020 Accepted: 14 October 2020

Published online: 27 October 2020

\section{References}

1. Roiz D, Wilson AL, Scott TW, Fonseca DM, Jourdain F, et al. Integrated Aedes management for the control of Aedes-borne diseases. PLoS Negl Trop Dis. 2018;12:e0006845.

2. Valle D, Belinato TA, Martins AJ. Controle químico de Aedes aegypti, resistência a inseticidas e alternativas. In: Valle D, Pimenta DN, Cunha RV, editors. Dengue: Teorias e Práticas. Rio de Janeiro: Fiocruz; 2015. p. 93-126.
3. Lima EP, Paiva MH, de Araújo AP, da Silva EV, da Silva UM, de Oliveira LN, et al. Insecticide resistance in Aedes aegypti populations from Ceará. Brazil Parsit Vectors. 2011;4:5

4. MS/SVS. Diretrizes nacionais para prevenção e controle de epidemias de dengue. Brasília: Ministério da Saúde/Secretaria de Vigilância em Saúde; 2009. https://bvsms.saude.gov.br/bvs/publicacoes/diretrizes_nacio nais_prevencao_controle_dengue.pdf.

5. SINAN Online/MS. Sistema de Informação de Agravos de Notificação/ Ministério da Saúde. Brasília: Ministério da Saúde. https://portalsina n.saude.gov.br/.

6. Roush RT. Designing resistance management programs: how can you choose? Pestic Sci. 1989;26:423-41.

7. Guedes RNC, Beins K, Navarro Costa D, Coelho GE, Bezerra HSdS. Patterns of insecticide resistance in Aedes aegypti: meta-analyses of surveys in Latin America and the Caribbean. Pest Manag Sci. 2020;76:2144-57.

8. Macoris MLG, Camargo MF, Silva IG, Takaku L, Andrighetti MTM. Modificação da susceptibilidade de Aedes (Stegomyia) aegypti ao temefós. Rev Pat Trop. 1995;24:31-40.

9. Valle D, Bellinato DF, Viana-Medeiros PF, Lima JBP, Junior AJM. Resistance to temephos and deltamethrin in Aedes aegypti from Brazil between 1985 and 2017. Mem Inst Oswaldo Cruz. 2019;114:e180544.

10. da-Cunha MP, Lima JBP, Brogdon WG, Moya GE, Valle D. Monitoring of resistance to the pyrethroid cypermethrin in Brazilian Aedes aegypti (Diptera: Culicidae) populations collected between 2001 and 2003. Mem Inst Oswaldo Cruz. 2005;100:441-4.

11. MS/SVS/CGPNCD. Reunião Técnica para Discutir Status de Resistência de Aedes aegypti. Rio de Janeiro: Ministério da Saúde/Secretaria de Vigilância em Saúde/Coordenação Geral do Programa Nacional de Controle da Dengue; 2006.

12. Braga IA, Valle D. Aedes aegypti: surveillance, resistance monitoring, and control alternatives in Brazil. Epidemiol Serv Saúde. 2007;16:295-302.

13. Marcombe $S$, Darriet $F$, Agnew P, Etienne M, Yp-Tcha MM, Yebakima A, et al. Field efficacy of new larvicide products for control of multi-resistant Aedes aegypti populations in Martinique (French West Indies). Am J Trop Med Hyg. 2011;84:1118-212.

14. Marcombe S, Farajollahi A, Healy SP, Clark GG, Fonseca DM. Insecticide resistance status of United States populations of Aedes albopictus and mechanisms involved. PLoS ONE. 2014;9:e101992.

15. Lau KW, Chen CD, Lee HL, Norma-Rashid Y, Sofian-Azirun M. Evaluation of insect growth regulators against field-collected Aedes aegypti and Aedes albopictus (Diptera: Culicidae) from Malaysia. J Med Entomol. 2015;52:199-206.

16. Su T, Thieme J, Lura T, Cheng ML, Brown MQ. Susceptibility profile of Aedes aegypti L. (Diptera: Culicidae) from Montclair, California, to commonly used pesticides, with note on resistance to pyriproxyfen. J Med Entomol. 2019;56:1047-54.

17. Macoris MLG, Andrighetti MTM, Otrera VCG, Carvalho LR, Júnior ALC, Brogdon WG. Association of insecticide use and alteration on Aedes aegypti susceptibility status. Mem Inst Oswaldo Cruz. 2007;102:895-900.

18. Goindin D, Delannay C, Gelasse A, et al. Levels of insecticide resistance to deltamethrin, malathion, and temephos, and associated mechanisms in Aedes aegypti mosquitoes from the Guadeloupe and Saint Martin islands (French West Indies). Infect Dis Poverty. 2017;6:38.

19. Chediak M, G Pimenta Jr F, Coelho GE, Braga IA, Lima JBP, Cavalcante KRLJ, et al. Spatial and temporal country-wide survey of temephos resistance in Brazilian populations of Aedes aegypti. Mem Inst Oswaldo Cruz. 2016;111:311-21.

20. Adegas MG, Barroso-Krause C, Lima JBP, et al. Parâmetros de Biossegurança para Insetários e Infectórios de Vetores: aplicação e adaptação das normas gerais para laboratórios definidas pela Comissão Técnica de Biossegurança da Fiocruz. Rio de Janeiro: Fiocruz; 2005. https://www. inctem.bioqmed.ufrj.br/index.php/pt/biblioteca/2964-parametros -de-biosseguranca-para-insetarios-e-infectorios-de-vetores-do-institutooswaldo-cruz.

21. Kuno G. Early history of laboratory breeding of Aedes aegypti (Diptera: Culicidae) focusing on the origins and use of selected strains. J Med Entomol. 2010;47:957-71.

22. WHO. Monitoring and managing insecticide resistance in Aedes mosquito populations. Interim guidance for entomologists. Geneva: World Health Organization; 2016. https://apps.who.int/iris/handle/10665/204588. 
23. Raymond M. Presentation d'une programme d'analyse logprobit pour microordinateur. Cah ORSTOM Ser Ent Med Parasitol. 1985;22:117-21.

24. WHO. Test procedures for insecticide resistance monitoring in malaria vector mosquitoes, 2nd ed. Geneva: World Health Organization; 2016. https://www.who.int/malaria/publications/atoz/9789241511575/en/.

25. Finney DJ. Probit analysis. London: Cambridge University; 1971.

26. Mazzarri MB, Georghiou GP. Characterization of resistance to organophosphate, carbamate, and pyrethroid insecticides in field populations of Aedes aegypti from Venezuela. J Am Mosq Control Assoc. 1995:11:315-22.

27. Andrighetti MTM, Cerone F, Rigueti M, Galvani KC, Macoris MLG. Effect of pyriproxyfen in Aedes aegypti populations with different levels of susceptibility to the organophosphate temephos. Dengue Bull. 2008;32:186-98.

28. Fonseca EOL, Macoris mLG, Santos RF, Morato DG, Isabel MDSS, Cerqueira NA, et al. Estudo experimental sobre a ação de larvicidas em populações de Aedes aegypti do município de Itabuna, Bahia, em condições simuladas de campo. Epidemiol Serviços Saúde. 2019;28:e2017316.

29. Linss JGB, Brito LP, Garcia GA, Araki AS, Bruno RV, Lima JBP, et al. Distribution and dissemination of the Val1016lle and Phe1534Cys Kdr mutations in Aedes aegypti Brazilian natural populations. Parasit Vectors. 2014;7:25.

30. Macoris MLG, Andrighetti MTM, Nalon KCR, Garbeloto VC, Caldas AL Jr. Standardization of bioassays for monitoring resistance to insecticides in Aedes aegypti. Deng Bul. 2005;29:176-82.

31. Macoris MLG, Andrighetti MTM, Wanderley DMV, Ribolla PEM. Impact of insecticide resistance on the field control of Aedes aegypti in the State of São Paulo. Rev Soc Bras Med Trop. 2014;47:573-8.
32. WHO. Prequalification vector control. Prequalified products 11 Apr 2019 https://www.who.int/pq-vector-control/prequalified-lists/en/. Accessed 2 Dec 2019.

33. Moyes CL, Vontas J, Martins AJ, Ng LC, Koou SY, Dusfour I, et al. Contemporary status of insecticide resistance in the major Aedes vectors of arboviruses infecting humans. PLoS Negl Trop Dis. 2017;11:e0005625.

34. Macoris MLG, Martins AJ, Andrighetti MTM, Lima JBP, Valle D. Pyrethroid resistance persists after ten years without usage against Aedes aegypti in governmental campaigns: lessons from São Paulo State. Brazil PLoS Negl Trop Dis. 2018;12:e0006390.

35. Wilson AL, Courtenay O, Kelly-Hope LA, Scott TW, Takken W, Torr SJ, et al. The importance of vector control for the control and elimination of vector-borne diseases. PLoS Negl Trop Dis. 2020;14:e0007831.

36. Achee NL, Grieco JP, Vatandoost H, Seixas G, Pinto J, Ching-Ng L, et al. Alternative strategies for mosquito-borne arbovirus control. PLoS Negl Trop Dis. 2019;13:e0006822. Erratum in: PLoS Negl Trop Dis. 2019;13:e0007275.

\section{Publisher's Note}

Springer Nature remains neutral with regard to jurisdictional claims in published maps and institutional affiliations.
Ready to submit your research? Choose BMC and benefit from:

- fast, convenient online submission

- thorough peer review by experienced researchers in your field

- rapid publication on acceptance

- support for research data, including large and complex data types

- gold Open Access which fosters wider collaboration and increased citations

- maximum visibility for your research: over 100M website views per year

At BMC, research is always in progress.

Learn more biomedcentral.com/submissions 